\title{
Terahertz pulse investigation of paleolithic wall etchings
}

Conference or Workshop Item

Accepted Version

Jackson, J. B., Walker, G., Roberts, J., Pike, A., De Talle, V., Giovannacci, D., Mourou, G., Menu, M. and Bowen, J. (2014)

Terahertz pulse investigation of paleolithic wall etchings. In: 39th Int. Conf. on Infrared, Millimeter, and THz Waves (IRMMW-THz), September 14-19, 2014, Tucson, Arizona, USA,. doi: https://doi.org/10.1109/IRMMW-THz.2014.6956054 Available at https://centaur.reading.ac.uk/36490/

It is advisable to refer to the publisher's version if you intend to cite from the work. See Guidance on citing.

To link to this article DOI: http://dx.doi.org/10.1109/IRMMW-THz.2014.6956054

All outputs in CentAUR are protected by Intellectual Property Rights law, including copyright law. Copyright and IPR is retained by the creators or other copyright holders. Terms and conditions for use of this material are defined in the End User Agreement.

\section{www.reading.ac.uk/centaur}

\section{CentAUR}


Central Archive at the University of Reading

Reading's research outputs online 


\title{
Terahertz Pulse Investigation of Paleolithic Wall Etchings
}

\author{
J. Bianca Jackson ${ }^{1}$, Gillian Walker ${ }^{1}$, John Roberts ${ }^{1}$, Alistair Pike ${ }^{2}$, Vincent DeTalle ${ }^{3}$, David \\ Giovannacci $^{3}$, Gerard Mourou ${ }^{4}$, Michel Menu ${ }^{5}$, and John Bowen ${ }^{1}$ \\ ${ }^{1}$ School of Systems Engineering, University of Reading, Reading, UK \\ ${ }^{2}$ Department of Archaeology, University of Southhampton, Southhampton, UK \\ 3LRMH, Champs-sur-Marne, FR \\ ${ }^{4}$ IZEST, Ecole Polytechnique, Palaiseau, FR \\ ${ }^{5}$ C2RMF, Palais du Louvre, Paris, FR
}

\begin{abstract}
Results are presented of an examination of flow rock-covered Paleoloithic cave art using time-domain terahertz reflectometry.
\end{abstract}

\section{INTRODUCTION}

$\mathrm{T}$ erahertz time-domain imaging and spectroscopy has been evolving as an investigative tool in the field of cultural heritage conservation [1]. Archaeological applications have included the study of corroded metal artifacts, sealed ceramic vessels, mummies, and stratified neolithic wall paintings [2]. This paper presents an extension of this repertoir of applications to include the imaging of prehistoric cave etchings partially-covered by natural flow rock.

In 2002, the first evidence of prehistoric cave art in Great Britain was discovered at Creswell Crags, on the DerbyshireNottinghamshire border [3]. Much of this art consists of etchings - patterns directly engraved into the rock using a sharp implement - which, unlike paintings, are difficult to recognize or see without a practiced eye. True prehistoric etchings can be distinguished from contemporary graffiti by the presence of a rock patina caused by prolonged weathering, exposure and precipitation, or by Uranium-series dating of the flow rock, i.e. layers of calcium precipitate deposits that overlie the art and magnesian limestone. The figures are estimated to be approximately $12 \mathrm{k}-15 \mathrm{k}$ years old.

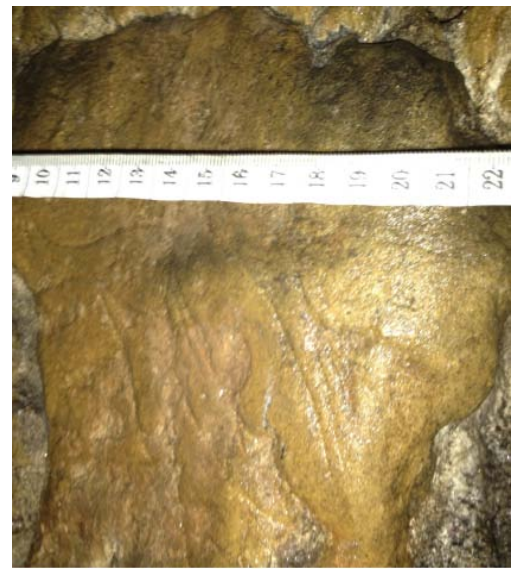

Fig. 1. Photograph of panel of bird etchings in Church Hole cave

Terahertz imaging experiments were conducted on one such panel in the Church Hole cave at Creswell Crags (fig. 1). The figures are series of semi-parallel lines, generally accepted to represent birds of indeterminate type. The lines are v-shaped grooves of depths and widths ranging from hundreds of micrometres to 3 millimetres.

\section{RESULTS}

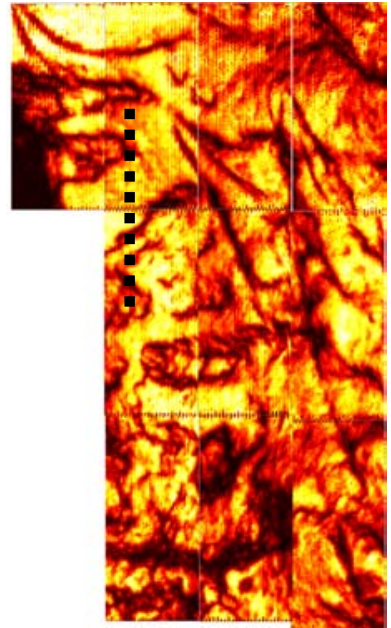

Fig. 2. (a) Composite of scanned sections of the bird etching and (b) selected

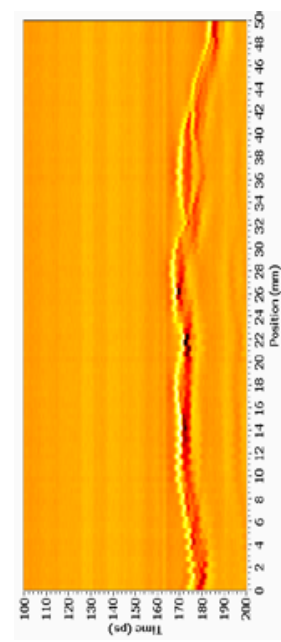

(b) b-scan cross-section.

Figure 2a shows the composite of several contiguous sections of the panel. The en face images were generated from the peak amplitude signal. The lines from the etching are clearly distinguishable from the other features of the rock. The more rounded, cloud-like shading could be a result of the nonflat surface of the cave due to weathering or flow rock. The dotted, black line denotes the location of the extracted b-scan cross-section in figure $2 \mathrm{~b}$. Here we can see variations in the signal suggesting two separate layers--the limestone subsurface with the calcite flow rock filling the grooves.

\section{SUMMARY}

This work demonstrates the potential of terahertz imaging as a tool for penetrating calcite flow rock to detect prehistoric rock art etched into limestone cave walls.

\section{REFERENCES}

[1]. J. B. Jackson, J. W. Bowen, G. C. Walker, J. Labaune, G. Mourou, M. Menu, and K. Fukunaga, "A Survey of Terahertz Applications in Cultural Heritage Conservation Science,” IEEE Trans. Terahertz Sci. Technol., vol. 1, no. 1, pp. 220-231, Sep. 2011.

[2]. G. C. Walker, J. W. Bowen, W. Matthews, S. Roychowdhury, J. Labaune, G. Mourou, M. Menu, I. Hodder, and J. B. Jackson, "Sub-surface terahertz imaging through uneven surfaces: visualizing Neolithic wall paintings in Çatalhöyük.," Opt. Express, vol. 21, no. 7, pp. 8126-34, Apr. 2013.

[3]. P. Pettitt, P. Bahn, and S. Ripoll, Palaeolithic Cave Art at Creswell Crags in European Context. 2007, pp. 1-309. 